\title{
Nitrogen Fixation In Methanogens: The Archaeal Perspective
}

\author{
John A. Leigh \\ Dept. Microbiology, University of Washington, Seattle, WA \\ 98195, USA
}

\begin{abstract}
The methanogenic Archaea bring a broadened perspective to the field of nitrogen fixation. Biochemical and genetic studies show that nitrogen fixation in Archaea is evolutionarily related to nitrogen fixation in Bacteria and operates by the same fundamental mechanism. At least six nif genes present in Bacteria (nif $H, D, K, E, N$ and $X$ ) are also found in the diazotrophic methanogens. Most nitrogenases in methanogens are probably of the molybdenum type. However, differences exist in gene organization and regulation. All six known nif genes of methanogens, plus two homologues of the bacterial nitrogen sensorregulator $g \ln B$, occur in a single operon in Methanococcus maripaludis. nif gene transcription in methanogens is regulated by what appears to be a classical prokaryotic repression mechanism. At least one aspect of regulation, post-transcriptional ammonia switch-off, involves novel members of the gInB family. Phylogenetic analysis suggests that nitrogen fixation may have originated in a common ancestor of the Bacteria and the Archaea.
\end{abstract}

\section{Introduction}

It has long been recognized that nitrogen fixation occurs in bacteria but not eukaryotes. When Archaea were first discovered to be a prokaryotic domain of life separate from Bacteria (1), it was not known that they too contained nitrogen fixing species. In 1984 S. Zinder and L. Daniels independently discovered diazotrophic growth in two different methanogenic Archaea, Methanosarcina barkeri (2) and Methanococcus thermolithotrophicus (3). ${ }^{15} \mathrm{~N}$ incorporation from ${ }^{15} \mathrm{~N}_{2}$ confirmed that nitrogen fixation occurred in $M$. barkeri, and acetylene reduction confirmed nitrogenase activity in $M$. thermolithotrophicus. This discovery of nitrogen fixation in Archaea raised new questions regarding the diversity of nitrogen fixation at the phylogenetic, biochemical, and genetic levels. A review on nitrogen fixation in methanogens appeared in 1992 (4).

\section{Distribution of Nitrogen Fixation in the Archaea}

The well-characterized Archaea consist of the strictly anaerobic methanogens, the extreme halophiles, and the extreme thermophiles (5). Some methanogens are also extreme thermophiles. The Archaea are distributed over two main phylogenetic branches (kingdoms) based on 16S
rRNA sequence comparisons, the Euryarchaeota and the Crenarchaeota (6). The Euryarchaeota contain the methanogens, the halophiles, and some extreme thermophiles, while the Crenarchaeota contain most of the extreme thermophiles. Within the Archaea, nitrogen fixation has been found only in the methanogenic Euryarchaeota. Within the methanogens, however, nitrogen fixation is widespread, extending to all three orders (7) (Table 1). In the Methanococcales, diazotrophic growth has been reported for Methanococcus thermolithotrophicus (3) and Methanococcus maripaludis (8). M. thermolithotrophicus is the only organism demonstrated to fix nitrogen at $60^{\circ} \mathrm{C}$ or above. Neither Methanococcus jannaschii (9) nor Methanococcus voltae (10) fix nitrogen despite the presence of nifH homologues (our unpublished results). In $M$. jannaschii it is clear that other nif genes are not present. Within the Methanomicrobiales, diazotrophic species include Methanosarcina barkeri $(2,11)$ and Methanospirillum hungatei (12). In the Methanobacteriales, nitrogen fixation has been demonstrated for Methanobacterium bryantii (12). Whether Methanobacterium thermoautotrophicum is a diazotrophic species is unclear. There is a report of diazotrophic growth of strain Marburg (13), and both strains Marburg and $\Delta \mathrm{H}$ have complete or nearly complete nif gene clusters compared to $M$. maripaludis (below). On the other hand, recent attempts to grow either strain diazotrophically have not been successful (R. Thauer, S. Zinder, personal communication). In addition, diazotrophic growth, ${ }^{15} \mathrm{~N}_{2}$ incorporation, or acetylene reduction has been reported for a number of other species of methanogens (4).

\section{How Different is Nitrogen Fixation in the Archaea?}

The discovery of nitrogen fixation in methanogens led to a quest to determine whether it resembled nitrogen fixation in Bacteria. Lobo and Zinder (15) presented evidence that diazotrophic growth in $M$. barkeri was energetically costly and was stimulated by molybdenum. Partial purification of nitrogenase activity revealed that two components were required (16). Subunit analysis suggested the presence of nitrogenase and nitrogenase reductase similar to those in Bacteria, except that the latter appeared to be a

Table 1. Nitrogen Fixing Species in the Archaea

Methanococcales
Methanococcus thermolithotrophicus
Methanococcus maripaludis
Methanomicrobiales
Methanosarcina barkeri
Methanospirillum hungatei
Methanobacteriales
Methanobacterium bryantii


homotetramer rather than a homodimer. The putative nitrogenase reductase cross-reacted with antiserum against nitrogenase reductase of Rhodospirillum rubrum. Whole cells, extracts, and purified nitrogenase could reduce acetylene to ethylene, albeit at lower rates than in Bacteria. nifH was cloned from $M$. thermolithotrophicus using a bacterial probe. Sequencing revealed nifD and part of nifK downstream from nifH (17). These findings suggested that nitrogen fixation in methanogens was evolutionarily related to nitrogen fixation in Bacteria and operated with the same basic mechanism.

If nitrogen fixation in Archaea fundamentally resembled nitrogen fixation in Bacteria, it seemed possible that Archaea might feature vanadium or iron-only nitrogenases that are present as "alternative" nitrogenases in certain Bacteria. However, this does not appear to be the case. The predominate nitrogenases in methanogens seem to be molybdenum nitrogenases as is the case in Bacteria (below).

\section{Genetics}

nif genes in methanogens were first cloned using nifH genes of Bacteria as hybridization probes (18). It soon became apparent that nifH genes in methanogens were followed by two genes with homology to $g \ln B$ (below), then nifD and nifK $(17,19)$. In $M$. maripaludis we used an oligonucleotide designed from a conserved region of nifH to clone a fragment from a DNA library (8). We used transposon insertion mutagenesis, a technique that we developed for $M$. maripaludis (8), to show that a region extending $8 \mathrm{~kb}$ from the beginning of $\mathrm{nifH}$ was required for diazotrophic growth (20). Sequencing this region identified the genes nifH through nif $X$ as shown in Figure 1. These genes are clear homologues of the corresponding genes in Bacteria, further demonstrating that nitrogen fixation in Archaea is fundamentally the same as in Bacteria. Five of these genes have functions in Bacteria that are required for and central to nitrogen fixation. nifH encodes nitrogenase reductase, nifD and nifK encode the $\alpha$ and $\beta$ subunits of nitrogenase itself, and nifE and nifN $N$ are required for iron-molybdenum cofactor (FeMoCo) synthesis (21). nif $X$ and the $g \ln B$ homologues are discussed below.

The nif gene organization found in $M$. maripaludis is conserved in other methanogens. In $M$. thermoautotrophicum a cluster with the same eight genes is present, with the sole exception that nif $X$ does not seem to be present in one strain $(\Delta \mathrm{H},(14))$, although it is found in another strain of the same species (Marburg, GenBank accession number 1854560). A corresponding gene cluster in $M$. barkeri has been sequenced from nifH through most of nifE (22), and it is likely that nifN and nif $X$ lie 3 ' to nifE. In
M. maripaludis, at least, the entire cluster of eight genes belongs to a single operon, since transposons inserted throughout the cluster always had a polar effect, that is, they always eliminated the synthesis of mRNA from genes $3^{\prime}$ to the insertion (20). Furthermore, an identifiable promoter sequence was present only in the region upstream of nifH. nif mRNA observed by Northern blot was usually fragmented into subsets of genes, and this could be attributed to some combination of intergenic termination of transcription and processing of the mRNA.

The organization of the methanogen nif gene cluster reveals differences as well as similarities when compared to bacteria. The order, nifH-nifD-nifK-nifE-nifN-nifX, is common in bacteria (21). However, the presence of novel homologues of $g \ln B$ (below) between nifH and nifD is unique to the methanogens. In addition, the presence of the six nif genes, nifH, nifD, nifK, nifE, nifN, and nif $X$ in a single operon is unknown in the Bacteria, which tend to separate the first three and the latter three into different operons (21).

Since nif $X$ is not required for nitrogen fixation in several Bacteria (21), we checked its function in M. maripaludis, taking advantage of genetic methods developed for Methanococcus species. An in-frame deletion mutant of nif $X$ was not detectably impaired in diazotrophic growth (23). nif $X$ has sequence homology to nifY and to the Cterminus of nifB, and it has been proposed that nif $X$ may have a dispensible function in FeMoCo synthesis that is duplicated by nifB or nifY (21). Whether $M$. maripaludis contains a functional nifB or nifY gene is unknown. nifB homologues (other than nifX) have been found in other methanogens $(9,14)$, but the homology does not extend to the C-terminal end of bacterial nifB. Therefore, the dispensibility of nif $X$ for nitrogen fixation in methanogens cannot easily be explained by gene duplication.

In contrast to the six nif genes of the nif operon in methanogens, in Klebsiella pneumoniae there are 20 different nif genes (21). It is at present unclear whether additional nifgenes function in diazotrophic methanogens. Neither a complete genome sequence, nor saturation mutagenesis, has yet been performed on a bona fide diazotrophic methanogen. It is possible that in methanogens only the six nif genes of the identified nif operon are functional homologues of bacterial nif genes. If this is the case, functions such as electron transport to the nitrogenase complex, nitrogenase protein maturation and stabilization, and homocitrate synthesis, may be carried out by the products of genes that do not have recognizable homology to bacterial nif genes. Genes with similarity to nifH, nifS, nifB, and nif $U$ have been found in nondiazotrophic Archaea $(9,24)$, so the presence of these genes alone does not imply a function in nitrogen fixation.

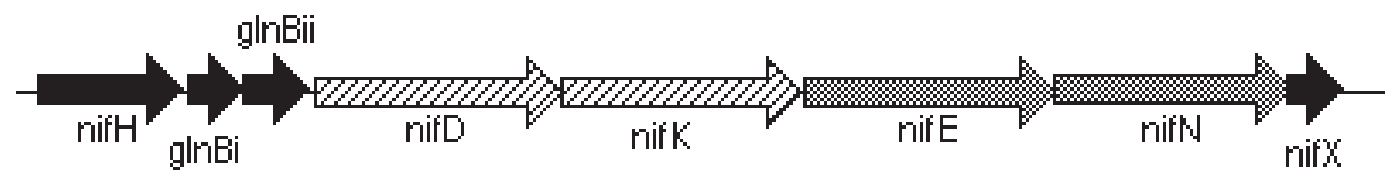

Figure 1. The nif gene operon of Methanococcus maripaludis. 


\section{Metals}

A number of workers have used diazotrophic growth assays to determine whether methanogens might contain alternative (vanadium or iron-only) nitrogenases as do some Bacteria. In one study, vanadium as well as molybdenum stimulated $M$. barkeri (25), while in another study only molybdenum was stimulatory (15). The presence of two genes in $M$. barkeri that are phylogenetically related to functional nifH genes (19) allows for the possibility that both molybdenum and vanadium nitrogenases are present in this organism, and recently a vanadium nitrogenase has been confirmed (25a). In M. maripaludis, molybdenum was clearly required for diazotrophic growth (26). Vanadium failed to stimulate, and tungsten inhibited, so this species may contain a single nitrogenase of the molybdenum type. The presence of molybdenum nitrogenases in other methanogens is corroborated by nif gene phylogeny (26), and by the apparent absence from the nif gene clusters of a gene corresponding to $v n f G$ or $a n f G$, which encode the $\delta$ subunits of alternative nitrogenases in Bacteria (27). Thus, molybdenum nitrogenases seem to predominate in methanogens, but vanadium nitrogenases may be present as well. Nitrogenases have not been purified sufficiently from methanogens to obtain a definitive metal content.

\section{Regulation}

\section{Transcriptional Regulation}

In M. thermolithotrophicus, mRNAs corresponding to nifH and nifD were reported to be present when $\mathrm{N}_{2}$ was the only nitrogen source but absent when ammonia was provided (17). In vitro transcription found no evidence for regulation (28), and it took in vivo genetic studies in $M$. maripaludis to identify regulatory features.

The regulation of nif transcription in $M$. maripaludis occurs by repression. This mechanism contrasts with the regulation of nif transcription in K. pneumoniae and other members of the Proteobacteria, which operates by an activation mechanism involving NifA. M. maripaludis contains two inverted repeats in the promoter region of the nif operon that are similar to repeats previously noted in M. thermolithothophicus (17) (Figure 2). We fused the nif promoter region of $M$. maripaludis to lacZ, mutagenized the inverted repeats, and showed that the sequence of the first inverted repeat is required for repression in the presence of ammonia (29). Extract from ammonia-grown cells caused a shift in the gel mobility of promoter region

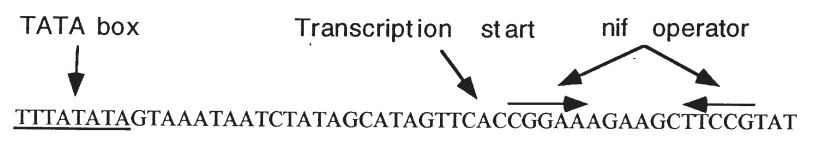

AATAACTAAAAGATCGGAAATAAATTCCGAAAGTCAACAATATATAGAGG

CCTAAAAAATG nif

Figure 2. nif promoter region of Methanococcus maripaludis. The TATA box, ribosome binding site, and translation start are underlined. Inverted repeats are indicated with arrows above.
DNA that depended on the first inverted repeat sequence. Presumably, a repressor protein in the extract bound to the inverted repeat. Therefore, nif transcription is regulated by repression and the first inverted repeat is the "nif operator". The second inverted repeat does not appear play a major role in regulation; but it could play a secondary role.

An inverted repeat similar to the nif operator of $M$. maripaludis, and matching the consensus GGAAN 6 TTCC, is a common feature in the promoter regions of nitrogenregulated genes in Methanococcus and Methanobacterium species (23). Genes for nitrogen fixation, ammonia assimilation (glutamine synthetase, $g \ln A$ ), ammonia or methylammonia transport (amtB), and the regulatory $\mathrm{G} \ln B$ protein, contain this sequence in their promoter regions. In the case of the $g \ln A$ gene in $M$. maripaludis, we have confirmed by mutagenesis that the inverted repeat sequence functions in repression (30). Thus, sequences that resemble the nif operator may mark genes that are coordinately regulated by a common repression mechanism. These genes may therefore belong to a "nitrogen regulon" in at least two genera of methanogens belonging to two different orders. Since nif gene transcription in methanogens appears to be regulated directly by this common nitrogen mechanism, it may not have an additional level of regulation specific to nitrogen fixation, as is the case involving NifA in Proteobacteria. However, there does appear to be a post-transcriptional mechanism specific to nitrogen fixation (below).

The repressor protein that binds to the nitrogen operator has not yet been identified, but one may speculate that it has dimeric nature and that each of two identical subunits binds to one half of the inverted repeat on the same face of the helix, as in the paradigm of bacterial repression. The evidence provided by the methanogen nif system, that regulation may resemble bacterial repression, is interesting because the basal transcription apparatus in Archaea resembles the eukaryal apparatus $(31,32)$.

In contrast, there is no evidence for a nitrogen operator sequence in $M$. barkeri. In that species, nif transcription may be regulated by a different negative mechanism in which a substance present in ammonia-grown cells inhibits binding of a transcription-associated protein or proteins to the promoter region (33). There is no evidence in this case that the inhibiting substance is itself a DNA-binding protein.

\section{Post-transcriptional Regulation and the Novel $g \ln B$ Homologues of the nif Gene Cluster}

The $g \ln B$ family of nitrogen sensory-regulatory genes is widespread. New glnB homologues have recently been discovered in Bacteria and Archaea, and it is beginning to appear likely that GInB proteins are involved in all aspects of nitrogen regulation in prokaryotes. Genome sequencing has revealed $g \ln B$ homologues, closely related to bacterial $g \ln B$ genes, in methanogens $(9,14)$. In addition to these genes, two unique subfamilies of $g \ln B$ homologues reside in the nif gene clusters of methanogenic Archaea (see for example Figure 1). Compared to "typical" glnB genes of Bacteria and Archaea, and compared to each other, these nif-cluster $g \ln B$ genes differ markedly in the T-loop region (Figure 3). In the well-characterized GInB protein, PII of Escherichia coli, the T-loop has been shown to contain the 
sites of interaction with other proteins that modulate the regulatory activity of $\mathrm{PII}$ or that transmit the nitrogen signal to regulatory targets (34). Therefore, the novel sequences of the regions corresponding to the T-loop indicate that the methanogen nif-cluster GInB proteins are likely to have novel interactions with other proteins.

We have recently determined the function of the nifcluster $g \ln B$ genes of $M$. maripaludis. Any function at the level of nif gene transcription was ruled out by the results of insertion mutagenesis across the nif cluster (20). (However, a function in transcriptional regulation for "typical" glnB genes encoded elsewhere in the genome is still possible). To test for other possible functions of the nifcluster glnB genes, we made an in-frame deletion mutation that eliminated most of both genes. We found (23) that the $g / n B$ mutant was deficient in ammonia switch-off, that is, in the immediate post-transcriptional inhibition of nitrogen fixation that occurs in some species $(35,36)$ upon addition of ammonia to nitrogen-fixing cultures. This finding shows that one or both of the nif-cluster glnB genes acts negatively to regulate nitrogen fixation at a post-transcriptional level. Switch-off also occurs in Methanosarcina barkeri $(15,16)$ and certain Bacteria (Rhodospirillum rubrum (35) and Azospirillum brasilense (36)), and while an involvement of $\mathrm{gln} B$ homologues is likely, it has not yet been demonstrated in these cases. It is known that ammonia switch-off in Bacteria is achieved through covalent ADP-ribosylation of nitrogenase reductase, controlled by a specific ADP-ribosyl transferase and a specific glycohydrolase. Similar covalent modification of nitrogenase does not appear to occur in methanogens (16, our unpublished results).
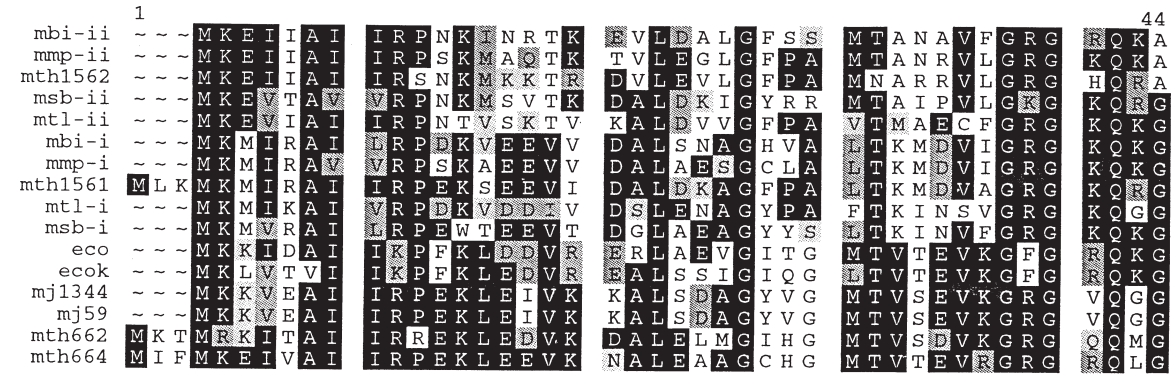

1-.-.T-loop---
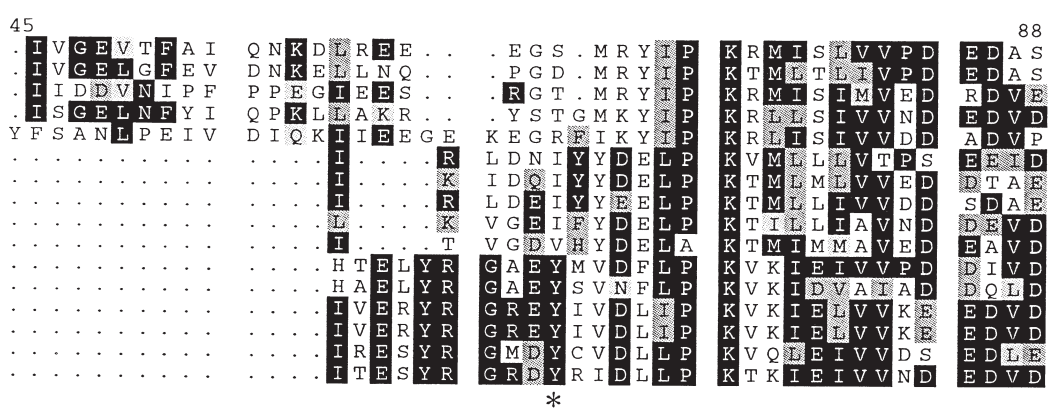

T-1oop-
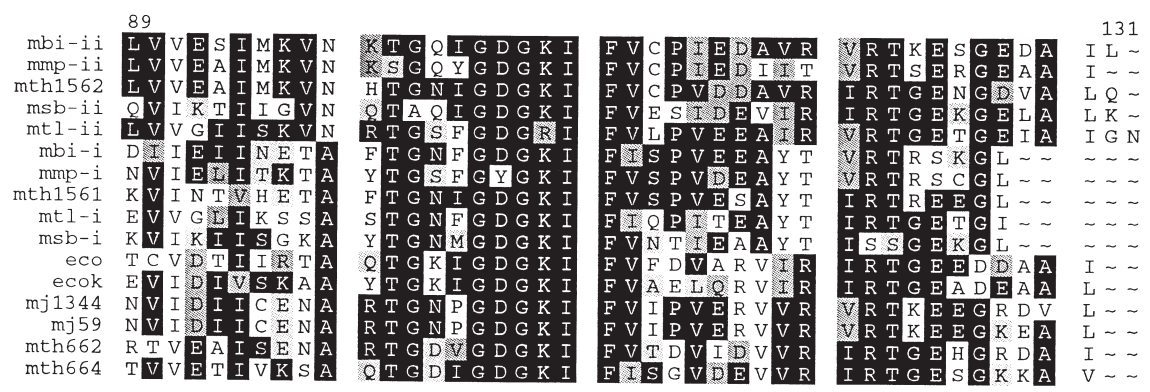

Figure 3. Alignment of $g \ln B$ homologues in Archaea and Bacteria. The top group of five represents the second glnB gene in the nif operon of methanogens (see for example Figure 1). The next group of five represents the first glnB gene in the nif operon of methanogens. The last group of six contains the "typical" glnB genes of Bacteria and methanogens. Species designations are as follows: mbi, Methanobacterium ivanovii; mmp, Methanococcus maripaludis; mth, Methanobacterium thermoautotrophicum strain DH; msb, Methanosarcina barkeri; $\mathrm{mtl}$, Methanococcus thermolithotrophicus; eco, Escherichia coli; mj, Methanococcus jannachii. Arabic numerals indicate gene designations relative to whole genome analyses $(9,14)$. The predicted T-loop is indicated $(39,40)$. * indicates the tyrosine reside which is the conserved site of uridylylation in Bacteria. 


\section{Evolution of Nitrogen Fixation}

The availability of nif gene sequences from Archaea expands our ability to trace the evolution of nitrogen fixation with phylogenetic methods. Expanding on the results of Chien and Zinder (22), we carried out a phylogenetic analysis of nifD and nifE (Figure 4). A separate analysis by parsimony gave essentially the same results as the distance matrix analysis. nifD and nifE are evidently paralogous, that is, related via an ancient gene duplication. Consequently, nifD genes provide a root for the nifE tree and vice versa. Each tree (nifD and nifE) contains two main branches. One branch is predominately bacterial, and the other branch contains nif genes of Archaea. This observation suggests that nitrogen fixation had its origin in a common ancestor of the two domains. Anabaena variabilis vnfE is anomalous, and is distant from both nifD and nifE of other species (37).
The overall pattern places the nif genes of Archaea and Bacteria into separate groups, but there are two exceptions. One exception is that for both nifE and nifD, Methanosarcina barkeriand Clostridium pasteurianum are closely related within a separate branch. In the case of nifE the M. barkeri - C. pasturianum clade groups with the Archaea with $100 \%$ bootstrap support. The simplest explanation is that $C$. pasteurianum acquired the nifgenes from an ancestor of $M$. barkeri by horizontal gene transfer. The nifD tree would suggest that the $M$. barkeri - $C$. pasteurianum clade groups with the Bacteria, but this is not supported by bootstrap analysis. The other exception to the Archaea-Bacteria split is that the alternative (vanadium and iron-only) nitrogenase subunit genes $v n f D$ and anfD (but not $v n f E$ ) of the Bacteria form a separate branch within the Archaea. $v n f D$ and $a n f D$ could have arisen through an ancient gene duplication that predates the Archaea-Bacteria split. Alternatively, they could have

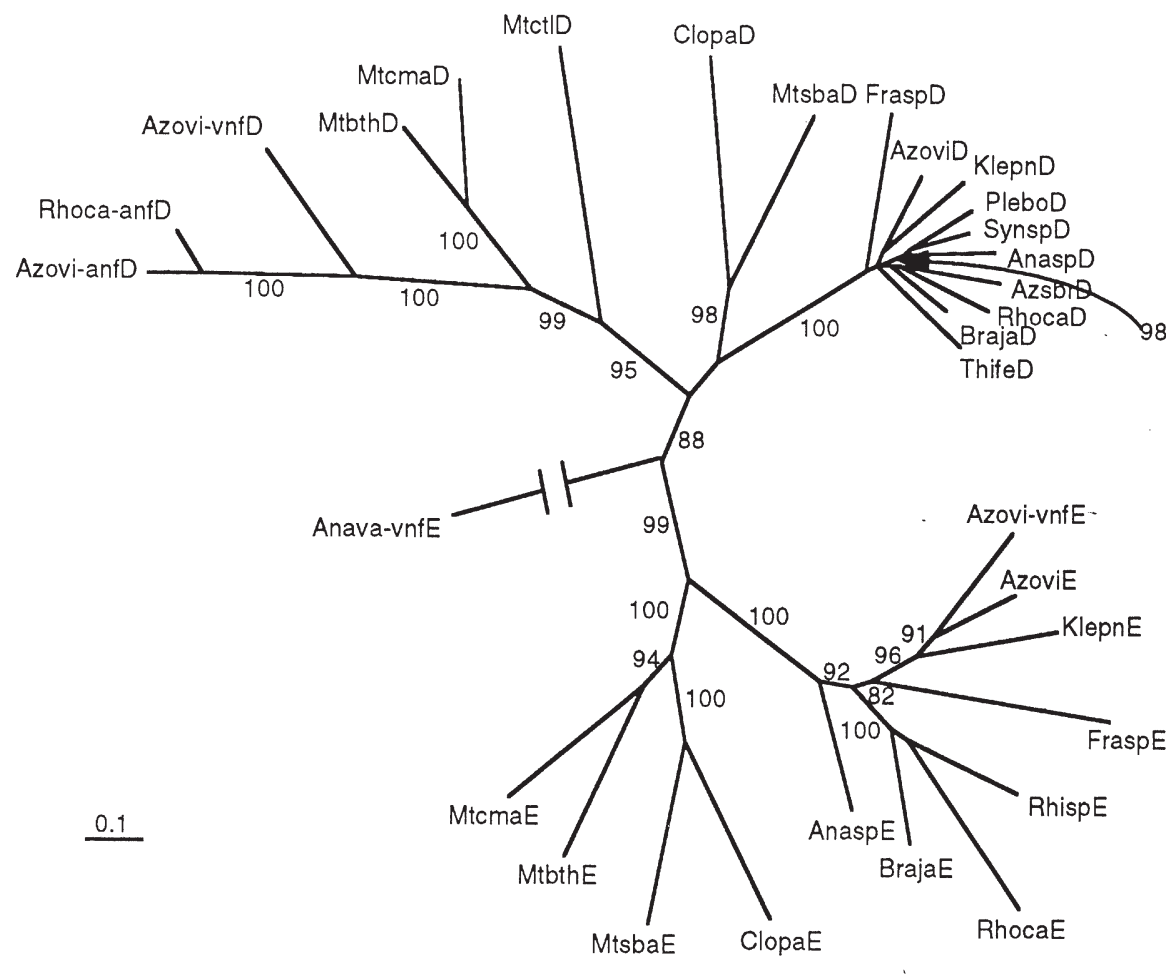

Figure 4. Phylogenetic analysis of nifD and nifE by distance matrix. Expert analysis kindly provided by A. Rodrigo. The computer program PROTDIST was used to estimate distances between all pairs of aligned amino acid sequences, using the Dayhoff PAM matrix. A phylogenetic tree was reconstructed using the computer program NEIGHBOR, which builds a tree by neighbor-joining (41). Both programs are part of the PHYLIP suite of programs (42). To determine the degree of support for each branch of the neighbor-joining phylogenetic tree, bootstrapping (43) was performed. 1000 pseudoreplicate sequence datasets were generated using SEQBOOT (also part of the PHYLIP suite), and for each pseudoreplicate, pairwise distances were estimated and the phylogenetic tree reconstructed. The number of trees which contained a given branch was counted and expressed as a percentage. Only those branches supported by more than $70 \%(44,45)$ of the bootstrap trees are shown. Alternative nitrogenase genes are designated vnf (vanadium type) and anf (iron-only type). Species designations are as follows: Anasp, Anabaena species; Anava, Anabaena variabilis; Azovi, Azotobacter vinelandii; Azsbr, Azospirillum brasilense; Braja, Bradyrhizobium japonicum; Clopa, Clostridium pasteurianum; Frasp, Frankia species; Klepn, Klebsiella pneumoniae; Mtbth, Methanobacterium thermoautotrophicum strain Marburg; Mtcma, Methanococcus maripaludis; Mtctl, Methanococcus thermolithotrophicus; Mtsba, Methanosarcina barkeri; Plebo, Plectonema boryanum; Rhisp, Rhizobium species; Rhoca, Rhodobacter capsulatus; Synsp, Synechococcus species; Thife, Thiobacillus ferrooxidans. 
evolved in the methanogen line and were passed by horizontal transfer to the Bacteria.

A parsimony analysis of nifK and nifN (not shown) gave results that were consistent with the conclusions from the nifD-nifE tree. Like nifD and nifE, nifK and nifN are paralogs. On the nifK side of the tree, bootstrap analysis strongly supported the discrete groups, bacterial nifK, bacterial vnfK and anfK, and methanogen nifK. C. pasteurianum and $M$. barkeri nifK formed a separate clade but with poor bootstrap support. On the nifN side, bacterial nifN formed a robust group that excluded methanogen nifN. In this case, bacterial $v n f N$ clustered with nifN from the same species.

Similar conclusions can also be drawn from the nifH tree. In these analyses $(26,38)$, there were four major branches. Three branches contained nifH genes that function in nitrogen fixation, while the fourth branch contained genes that evidently participate in a process unrelated to nitrogen fixation. Bacterial and archaeal nifH genes fell in two separate major branches. C. pasteurianum and $M$. barkeri nifH were closely related and formed a third major branch. anfH genes of bacteria fell in the archaeal branch. ( $v n f H$ genes, however, clustered with bacterial nifH).

These analyses all support a scenario in which nitrogen fixation had an ancient origin that preceded the divergence of Archaea and Bacteria. In addition, ancient gene duplication or horizontal transfer participated in the evolution of the alternative nitrogenase genes anfH, vnfD, anfD, vnfK and anfK, which remarkably are equally divergent from typical bacterial nif genes as are the methanogen nifgenes. On the other hand, $v n f H, v n f E$, and $v n f N$ evolved recently from the corresponding nif genes of Bacteria. Finally, horizontal gene transfer apparently occurred between ancestors of $M$. barkeri and $C$. pasteurianum.

\section{Conclusions and Future Directions}

Since the discovery of nitrogen fixation in methanogenic Archaea, it has become clear that the process is genetically and evolutionarily related to nitrogen fixation in Bacteria. However, phylogenetic analysis suggests that the relationship is as distant as are the two domains themselves. Given this distance, one expects to find in it the extremities in variations to the fundamental mechanism, making those aspects that are conserved all the more notable. The presence of nifH, D, K, E, N, and $X$, their gene order, and even whether they are essential for nitrogen fixation, is conserved. However, more work is needed to tell whether additional nif genes, less central to the process but nevertheless necessary in Bacteria, also exist in Archaea. The predominance of molybdenum as a metal of the nitrogenase cofactor also seems to extend across domains. Regulation varies across domains but also contains conserved features. The regulation of nif gene transcription in some methanogenic species involves repression, but the components of the nitrogen sensoryregulatory apparatus have yet to be identified. $g \ln B$ homologues are present in both domains and may turn out to represent components of the regulatory apparatus in methanogens. We know already that divergent members of the $g \ln B$ family exist in methanogens as well as less divergent members, and the former function in posttranscriptional regulation of nitrogenase activity. Further work on nitrogen fixation in Archaea is sure to reveal additional variations on familiar paradigms.

\section{References}

1. Woese, C.R., and Fox, G.E. 1977. Phylogenetic structure of the prokaryotic domain: the primary kingdoms. Proc. Acad. Natl. Sci. USA.74:5088-90.

2. Murray, P.A., and Zinder, S.H. 1984. Nitrogen fixation by a methanogenic archaebacterium. Nature. 312:284-286.

3. Belay, N., Sparling, R., and Daniels, L. 1984. Dinitrogen fixation by a thermophilic methanogenic bacterium. Nature. 312:286-8

4. Lobo, A.L., and Zinder, S.H. Nitrogen fixation by methanogenic bacteria. 1992. In: Biological Nitrogen Fixation. Stacey, G., Burris, R.H., and Evans, H.J., eds. Chapman and Hall, New York. p.191-211.

5. Pace, N.R. 1997. A molecular view of microbial diversity and the biosphere. Science. 276:734-40.

6. Woese, C.R., Kandler, O., and Wheelis, M.L. 1990. Towards a natural system of organisms: proposal for the domains Archaea, Bacteria, and Eucarya. Proc. Acad. Natl. Sci. USA. 87: 4576-9.

7. Whitman, W.B., Bowen, T.L., and Boone, D.R. The methanogenic bacteria. 1992. In: The Prokaryotes. Balows, A., Truper, H.G., Dworkin M., Harder, W., and Schleifer, K.-H., eds. Springer-Verlag, New York. p. 719-767.

8. Blank, C.E., Kessler, P.S., and Leigh, .JA. 1995. Genetics in methanogens: transposon insertion mutagenesis of a Methanococcus maripaludis nifH gene. J. Bacteriol. 177: 5773-7.

9. Bult, C.J., White, O., Olsen, G.J., et al. 1996. Complete genome sequence of the methanogenic archaeon, Methanococcus jannaschii. Science. 273: 1058-73.

10. Sibold, L., and Souillard, N. 1988. Genetic analysis of nitrogen fixation in methanogenic archaebacteria. In: Nitrogen Fixation: Hundred Years After. Bothe, H., de Bruijn, F.J., and Newton, W.E., eds. Gustav Fischer, New York. p.705-710.

11. Bomar, M., Knoll, K., and Widdel, F. 1985. Fixation of molecular nitrogen by Methanosarcina barkeri. FEMS Microbiol. Ecol. Lett. 31: 47-55.

12. Belay, N., Sparling, R., Choi, B.S., Roberts, M., Roberts, J.E., and Daniels, L. 1988. Physiological and ${ }^{15} \mathrm{~N}-\mathrm{NMR}$ analysis of molecular nitrogen fixation by Methanococcus thermolithotrophicus, Methanobacterium bryantii and Methanospirillum hungatei. Biochim Biophys Acta. 971: 233-45.

13. Fardeau, M.-L., Peillex, J.-P., and Belaich, J.-P. 1987. Energetics of the growth of Methanobacterium thermoautotrophicum and Methanococcus thermolithotrophicus on ammonium chloride and dintirogen. Arch. Microbiol. 148: 128-131.

14. Smith, D.R., Doucette-Stamm, L.A,, Deloughery, C., et al. 1997. Complete genome sequence of Methanobacterium thermoautotrophicum deltaH: functional analysis and comparative genomics. J. Bacteriol. 179: 7135-55.

15. Lobo, A.L., and Zinder, S.H. 1988. Diazotrophy and nitrogenase activity in the archaebacterium Methanosarcina barkeri 227. Appl. Environ. Microbiol. 54: 1656-1661.

16. Lobo, A.L., and Zinder, S.H. 1990. Nitrogenase in the archaebacterium Methanosarcina barkeri 227. J. Bacteriol. 172: 6789-96.

17. Souillard, N., and Sibold, L. 1989. Primary structure, functional organization and expression of nitrogenase structural genes of the thermophilic archaebacterium Methanococcus thermolithotrophicus. Mol. Microbiol 3: 541-51.

18. Souillard, N., Magot, M., Possot, O., and Sibold, L. 1988. Nucleotide sequence of regions homologous to nifH (nitrogenase Fe protein) from the nitrogen-fixing archaebacteria Methanococcus thermolithotrophicus and Methanobacterium ivanovii: evolutionary implications. J. Mol. Evol. 27: 65-76.

19. Sibold, L., Henriquet, M., Possot, O., and Aubert, J.P. 1991. Nucleotide sequence of nifH regions from Methanobacterium ivanovii and Methanosarcina barkeri 227 and characterization of $g \ln B$-like genes. Res. Microbiol 142: 5-12.

20. Kessler, P.S., Blank, C., and Leigh, J.A. 1998. The nif gene operon of the methanogenic archaeon Methanococcus maripaludis. J. Bacteriol. 180: 1504-11.

21. Dean, D.R., and Jacobson, M.R. Biochemical genetics of nitrogenase. 1992. In: Biological Nitrogen Fixation. Stacey, G., Evans, H.J., and Burris, R.H., eds. Chapman and Hall, New York. p. 763-834.

22. Chien, Y.T., and Zinder, S.H. 1996. Cloning, functional organization, transcript studies, and phylogenetic analysis of the complete 
nitrogenase structural genes (nifHDK2) and associated genes in the archaeon Methanosarcina barkeri 227. J. Bacteriol. 178: 143-8.

23. Kessler, P.S., and Leigh, J.A. 1999. Genetics of nitrogen regulation in Methanococcus maripaludis. Genetics. 152: 1343-1351.

24. Klenk, H.P., Clayton, R.A., Tomb, J.F., et al. 1997. The complete genome sequence of the hyperthermophilic, sulphate- reducing archaeon Archaeoglobus fulgidus [published erratum appears in Nature. $1998 \mathrm{Jul} 2$; 394 (6688): 101]. Nature. 390: 364-70.

25. Scherer, P. 1989. Vanadium and molybdenum requirement for the fixation of molecular nitrogen by two Methanosarcina strains. Arch. Microbiol. 151: 44-48.

25a. Chien, Y.-T., Auerbuch, V., Brabban, A.D., and Zinder, S.H. 2000 Analysis of genes encoding an alternative nitrogenase in the archaeon Methanosarcina barkeri 227. J. Bacteriol. 182: 3247-53.

26. Kessler, P.S., McLarnan, J., and Leigh, J.A. 1997. Nitrogenase phylogeny and the molybdenum dependence of nitrogen fixation in Methanococcus maripaludis. J. Bacteriol. 179: 541-3.

27. Bishop, P.E., and Premakumar, R. Alternative nitrogen fixation systems. 1992. In: Biological Nitrogen Fixation. Stacey, G., Burris, R.H., and Evans, H.J., eds. Chapman and Hall, New York . p. 736762.

28. Gohl, H.P., Hausner, W., and Thomm, M. 1992. Cell-free transcription of the nifH1 gene of Methanococcus thermolithotrophicus indicates that promoters of archaeal nif genes share basic features with the methanogen consensus promoter. Mol. Gen. Genet. 231: 286-95.

29. Cohen-Kupiec, R., Blank, C., and Leigh, J.A. 1997. Transcriptional regulation in Archaea: in vivo demonstration of a repressor binding site in a methanogen. Proc. Acad. Natl. Sci. USA. 94: 1316-20.

30. Cohen-Kupiec, R., Marx, C.J., and Leigh, J.A. 1999. Function and regulation of $g \ln A$ in the methanogenic archaeon Methanococcus maripaludis. J. Bacteriol. 181: 256-261.

31. Reeve, J.N., Sandman, K., and Daniels, C.J. 1997. Archaeal histones, nucleosomes, and transcription initiation. Cell. 89: 999-1002.

32. Leigh, J.A. 1999. Transcriptional regulation in Archaea. Current Opin. Microbiol. 2: 131-134.

33. Chien, Y., Helmann, J.D., and Zinder, S.H. 1998. Interactions between the promoter regions of nitrogenase structural genes (nifHDK2) and DNA-binding proteins from $\mathrm{N}_{2}$ - and ammonium-grown cells of the archaeon Methanosarcina barkeri 227. J. Bacteriol. 180: 2723-8.

34. Jiang, P., Zucker, P., Atkinson, M.R., Kamberov, E.S., Tirasophon, W., Chandran, P., Schefke, B.R., and Ninfa, A.J. 1997. Structure/ function analysis of the PII signal transduction protein of Escherichia coli: genetic separation of interactions with protein receptors. J. Bacteriol. 179: 4342-53.

35. Liang, J.H., Nielsen, G.M., Lies, D.P., Burris, R.H., Roberts, G.P., and Ludden, P.W. 1991. Mutations in the draT and draG genes of Rhodospirillum rubrum result in loss of regulation of nitrogenase by reversible ADP-ribosylation. J. Bacteriol. 173: 6903-9.

36. Zhang, Y., Burris, R.H., Ludden, P.W., and Roberts, G.P. 1993. Posttranslational regulation of nitrogenase activity by anaerobiosis and ammonium in Azospirillum brasilense. J. Bacteriol. 175: 6781-8.

37. Thiel, T. 1996. Isolation and characterization of the VnfEN genes of the cyanobacterium Anabaena variabilis. J. Bacteriol. 178: 4493-9.

38. Chien, Y.T., and Zinder, S.H. 1994. Cloning, DNA sequencing, and characterization of a nifD-homologous gene from the archaeon Methanosarcina barkeri 227 which resembles nifD1 from the eubacterium Clostridium pasteurianum. J. Bacteriol. 176: 6590-8.

39. Xu, Y., Cheah, E., Carr, P.D., van Heeswijk, W.C., Westerhoff, H.V., Vasudevan, S.G., and Ollis, D.L. 1998. GInK, a PII-homologue: structure reveals ATP binding site and indicates how the T-loops may be involved in molecular recognition. J. Mol. Biol. 282: 149-65.

40. Carr, P.D., Cheah, E., Suffolk, P.M., Vasudevan, S.G., Dixon, N.E. and Ollis, D.L. 1996. X-ray structure of the signal transduction protein PII from Escherichia coli at 1.9 A. Acta Crystallog. Sect. D 52: 93-104.

41. Saitou, N., and Nei, M. 1987. The neighbor-joining method: a new method for reconstructing phylogenetic trees. Mol. Biol. Evol. 4: 40625.

42. Felsenstein, J. 1989. PHYLIP - Phylogeny inference package. Cladistics. 5: 164-166.

43. Felsenstein, J. 1985. Confidence limits on phylogenies: an approach using the bootstrap. Evol. 39: 783-791.

44. Rodrigo, A.G. 1993. Calibrating the bootstrap test of monophyly. Int. J. Parasitol. 23: 507-14.

45. Zharkikh, A., and Li, W.-H. 1992. Statistical properties of bootstrap estimation of phylogenetic variability from nucleotide sequences. II. Four taxa without a molecular clock. J. Mol. Evol. 35: 356-366. 


\section{Further Reading}

Caister Academic Press is a leading academic publisher of advanced texts in microbiology, molecular biology and medical research. Full details of all our publications at caister.com

- MALDI-TOF Mass Spectrometry in Microbiology Edited by: M Kostrzewa, S Schubert (2016) www.caister.com/malditof

- Aspergillus and Penicillium in the Post-genomic Era Edited by: RP Vries, IB Gelber, MR Andersen (2016) www.caister.com/aspergillus2

- The Bacteriocins: Current Knowledge and Future Prospects Edited by: RL Dorit, SM Roy, MA Riley (2016)

www.caister.com/bacteriocins

- Omics in Plant Disease Resistance Edited by: V Bhadauria (2016) www.caister.com/opd

- Acidophiles: Life in Extremely Acidic Environments Edited by: R Quatrini, DB Johnson (2016) www.caister.com/acidophiles

- Climate Change and Microbial Ecology: Current Research and Future Trend

Edited by: J Marxsen (2016)

www.caister.com/climate

- Biofilms in Bioremediation: Current Research and Emerging Technologies

Edited by: G Lear (2016)

www.caister.com/biorem

- Microalgae: Current Research and Applications Edited by: MN Tsaloglou (2016) www.caister.com/microalgae

- Gas Plasma Sterilization in Microbiology: Theory, Applications, Pitfalls and New Perspectives Edited by: H Shintani, A Sakudo (2016) www.caister.com/gasplasma

- Virus Evolution: Current Research and Future Directions Edited by: SC Weaver, M Denison, M Roossinck, et al. (2016) www.caister.com/virusevol

- Arboviruses: Molecular Biology, Evolution and Control Edited by: N Vasilakis, DJ Gubler (2016) www.caister.com/arbo

- Shigella: Molecular and Cellular Biology Edited by: WD Picking, WL Picking (2016) www.caister.com/shigella

-Aquatic Biofilms: Ecology, Water Quality and Wastewater Treatment

Edited by: AM Romaní, H Guasch, MD Balaguer (2016)

www.caister.com/aquaticbiofilms

- Alphaviruses: Current Biology

Edited by: S Mahalingam, L Herrero, B Herring (2016)

www.caister.com/alpha

- Thermophilic Microorganisms

Edited by: F Li (2015)

www.caister.com/thermophile
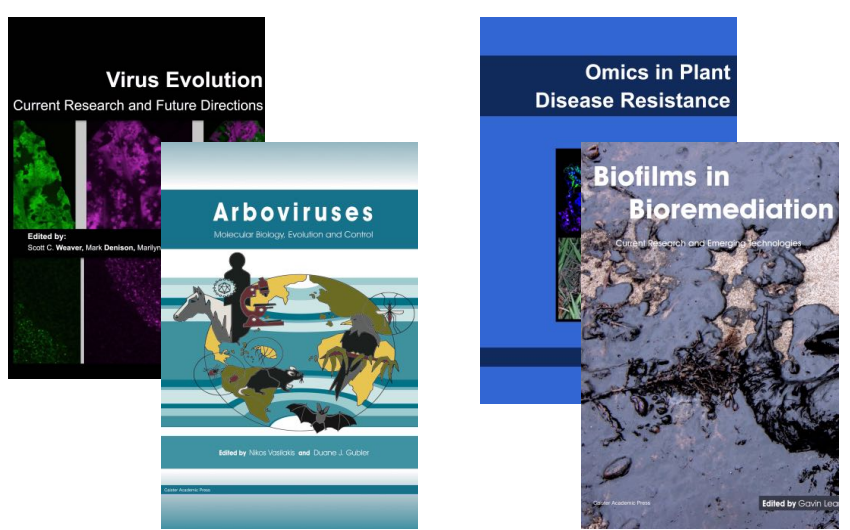
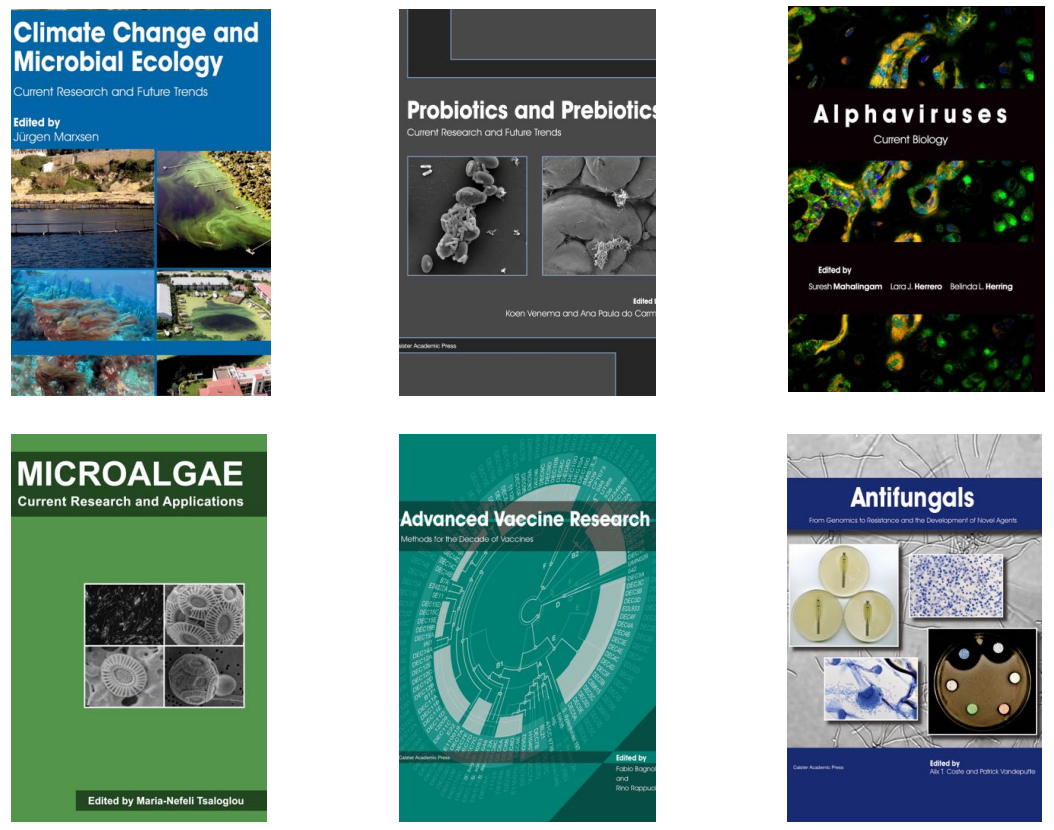

- Flow Cytometry in Microbiology: Technology and Applications Edited by: MG Wilkinson (2015) www.caister.com/flow

- Probiotics and Prebiotics: Current Research and Future Trends Edited by: K Venema, AP Carmo (2015) www.caister.com/probiotics

- Epigenetics: Current Research and Emerging Trends Edited by: BP Chadwick (2015) www.caister.com/epigenetics2015

- Corynebacterium glutamicum: From Systems Biology to Biotechnological Applications

Edited by: A Burkovski (2015)

www.caister.com/cory2

- Advanced Vaccine Research Methods for the Decade of Vaccines

Edited by: F Bagnoli, R Rappuoli (2015)

www.caister.com/vaccines

- Antifungals: From Genomics to Resistance and the Development of Novel Agents

Edited by: AT Coste, P Vandeputte (2015)

www.caister.com/antifungals

- Bacteria-Plant Interactions: Advanced Research and Future Trends Edited by: J Murillo, BA Vinatzer, RW Jackson, et al. (2015) www.caister.com/bacteria-plant

\section{- Aeromonas}

Edited by: J Graf (2015)

www.caister.com/aeromonas

- Antibiotics: Current Innovations and Future Trends

Edited by: S Sánchez, AL Demain (2015)

www.caister.com/antibiotics

- Leishmania: Current Biology and Contro Edited by: S Adak, R Datta (2015) www.caister.com/leish2

- Acanthamoeba: Biology and Pathogenesis (2nd edition) Author: NA Khan (2015)

www.caister.com/acanthamoeba2

- Microarrays: Current Technology, Innovations and Applications Edited by: Z He (2014)

www.caister.com/microarrays2

- Metagenomics of the Microbial Nitrogen Cycle: Theory, Methods and Applications

Edited by: D Marco (2014)

www.caister.com/n2 